УДК 304.444, $314.1(571.511)+314.1(571.512)$

\title{
The Method of Expert Interview \\ as an Effective Research Procedure of Studying \\ the Indigenous Peoples of the North
}

\author{
Natalia M. Libakova and Ekaterina A. Sertakova* \\ Siberian Federal University \\ 79 Svobodny, Krasnoyarsk, 660041, Russia
}

Received 13.04.2014, received in revised form 21.05.2014, accepted 30.06.2014

This article analyzes the concept of "indigenous peoples", as well as the concept of indigeneity that was formed in cultural studies and that implies a specific approach to the study of ethnic cultures in their self-sufficiency. One effective way of meeting the requirements of this approach is the expert interview. This article discusses the possibility of applying this method in studies of indigenous peoples of the North to the material collected by scholars, masters and students of Siberian Federal University during an expedition to the north of the Krasnoyarsk Krai.

The work was performed as a part of the research funded by the Krasnoyarsk Regional Fund of Support for Scientific and Technological Activities, as well as within the research plan of SibFU following the instructions of the Ministry of Education and Science of the Russian Federation.

Keywords: indigenous peoples, indigenous peoples of the North, ethnic identity, cultural studies, research procedures, method of expert interview.

Research area: culture studies.

At present the study of indigenous peoples of the North is one of the central themes in various social sciences and humanities. This interest in the subject is due to several reasons. The first is that in the context of global transformations the influence of "big" cultures on indigenous peoples is constantly increasing and there is a need to preserve these "minor" cultures. (Berry, Dasen, Purtinga, Sigal 2007). Secondly, the study of indigenous peoples' specifics and finding ways to preserve their unique cultures is particularly relevant in terms of industrial development of the North.
This is an active area of research for both: domestic and foreign scholars. J.W. Fenelon, S.J. Murgua, M.B. Lane, M. Hibbard, M.L. Martello, S.E. Mills, A. Feldman, E.A. Korczak, N.A. Khrenov, F.H. Sokolova, S.V. Guzenina, N.P. Koptseva, V.I. Kirko, V.P. Krivonogov, N.I. Novikova, etc. made a significant contribution to the study of indigenous peoples. Today a relevant question remains concerning the type of methodology to be applied to this kind of research, because results and conclusions obtained through this research to a certain extent determine the future of these peoples: whether they can or cannot maintain

(C) Siberian Federal University. All rights reserved

* Corresponding author E-mail address: sertachok@mail.ru 
their own identity and uniqueness of culture in the global transformations, otherwise assimilation is going to take place.

The degree of validity of results is significant for any empirical research (Savage, 2013), that is the correspondence between the results obtained in the study and reality. The degree of validity is initially conditioned by the method or procedure which it is supposed to be used for research, so in this regard the choice of methods, techniques, and development of methodological strategy are of paramount importance. It is fair to note that this choice is due to the specifics of the research object. The expert interview is one of effective methods of studying indigenous peoples of the North. Peculiarities of this method allow to get a glimpse at these peoples from the "internal" point of view (emic standpoint) (Triandis, Gerardo, 1983), this position corresponds to the concept of indigeneity.

\section{The Concept of Indigeneity in Cultural Studies}

The Russian concept “индигенный” comes from the English word "indigenous". However the interpretation of the content of this concept remains fuzzy. The problem of translation and understanding of this term was in the focus of attention of western scholars W. Dallmann and H. Goldman (Dallmann, Goldman, 2003).

Scholars point to the fact that only the social and political context makes the fundamental choice for the use of the words "native", "indigenous" or "aboriginal". In particular this choice becomes of substantial importance when relating to the relationship between those who originally occupied a certain territory and those who came to this territory as colonists.

Nevertheless, there is a legal, international standard for the use of the term "indigenous", stated in the ILO Convention No.169 (1989) (The International Labour Organization), also referred to as "Indigenous and Tribal Peoples Convention". This document focuses on giving peoples an opportunity to preserve and develop their unique cultural characteristics in a different mainstream society. Indigenous and tribal peoples in the Convention are defined as follows:

1) tribal peoples in independent countries whose social, cultural and economic conditions distinguish them from other sections of the national community, and whose status is regulated wholly or partially by their own customs or traditions or by special laws or regulations;

2) peoples in independent countries who are regarded as indigenous on account of their descent from the populations which inhabited the country, or a geographical region to which the country belongs, at the time of conquest or colonization or the establishment of present state boundaries and who, irrespective of their legal status, retain some or all of their own social, economic, cultural and political institutions (Dallmann, Goldman, 2003).

W. Dallmann and H. Goldman also made analysis of understanding of the term “индигенный” (indigenous) in Russia. The researchers note that understanding of the term by the Russian public largely does not coincide with the West. This is due to the specifics of Russian history, changes in the policy of the Russian Empire through the Soviet Union to the Post-Soviet Russia. This in turn causes difficulties in determining the status of indigenous peoples, and in defining a certain group of peoples as indigenous.

Among Russian researchers the problem of determining the meaning of indigenous people is developed by M.S. Kuropyatnik, Doctor of Social Sciences, Professor of St. Petersburg State University. The researcher analyzes the significance and place of the concept of "indigenous" in political and scientific academic discourse, the transformation of this concept 
under the influence of various socio-cultural factors (Kuropyatnik, 2002).

In cultural studies, the formation of the concept of indigeneity has methodological significance and is associated with the protest of non-Western cultures against the use of standardized research procedures in the study of different cultures. The concept of indigeneity is considered to be a peculiar reaction "to the lack of theories of individualism, typical for the West" (Markus, Kitayama, 1998), as opposition to the positivist approach, which is characterized by the use of a standardized research methodology, despite the fact that it can lead to erroneous interpretation of the empirical data. The concept of indigeneity has grown on a foundation of classic works: Philosophy of Culture by O. Spengler, who stipulated the idea of existence of a number of local equal cultures, the writings of F. Boas, the founder of the school of cultural anthropology. The researchers prove inadmissibility of the use of general theories and the standardized methodology in cultural studies; they highlight the need to study each culture in its self-sufficiency.

\section{Possible Applications of Expert Interviews in Cultural Studies}

The expert interview is one of the methods that conform to the concept of indigeneity. In scientific knowledge the interview is traditionally attributed to sociological methods (Bell, Braymen, 2012), but its scope today is far beyond the scope of the theory of society. Interviews are widely used in the humanities and technical research to study a wide range of issues. Therefore, we can say that it is rather an interdisciplinary method, the use of which is determined only on the basis of research tasks (Ruppert, Law, Savage, 2013).

Attention to the interview as a qualitative method, the use of which is possible in the humanities began to emerge in the last quarter of the $20^{\text {th }}$ century, but today its necessity is perceived as a well-established fact. A number of modern scholars, among which are S.J. Thompson, D.M. Davis, R. Merton, M. Fiske, P. Kendall, V.I. Ilyin, V.A. Kurennoy, M.M. Lukin, M. Ermoshin and many others note many advantages of the interview method.

"Interview" is a conversation with a set purpose and set tasks which are related to obtaining information relevant to the ongoing research. Interviews (literally meaning "opinion in between") during the survey involve an exchange of opinions between interlocutors (an interviewer and a respondent), thereby generating another value - the construction of new knowledge, the formation of new content.

As noted by a leading European specialist in qualitative research S. Kvale: "the form of conversation today is a necessary condition to obtain knowledge about the inner world and social life, including also academic knowledge". According to him, the research interview is the best way of finding the quality and content of information required to solve research problems of humanities.

Interviews can be formalized, un-formalized and semi-formalized.

The formalized interview presupposes composed questions of a closed type, where the researcher selects some necessary answer variants. This type of interview is focused primarily on receiving expected, homogeneous information from respondents. Therefore, its use is often associated with the study of public opinion on various issues. In a study using a formalized interview the range of sampling should be large enough. Depending on the required specification of the number of respondents results can vary from a couple hundred to several thousand people.

Principles of development and implementation of formal interviews today are 
well studied and are presented in a number of works of Russian and foreign scholars. As for non-formalized methods of the interview, this area remains less meaningful. Only recently began to appear works whose authors (Chekhov, 2009; Risman, 2009; Miagkov, Zhuravlev, 2005) try to fill in evident gaps in its understanding.

In studies which use the method of nonformal interview even one survey respondent can be quite representative and the information can be exhaustive. However, the researcher makes a decision about how many people he (or she) needs to interview, and whether it would be sufficient for the task. The duration of non-formal interviews exceeds the time spent on formalized questions and can last for several hours.

The non-formalized interview has an extensive range of issues that do not require comparing questions to answers. This type of interview is interesting due to the fact that different respondents provide different information or voice personal opinions relating to the proposed questions. Hence, the researcher can choose: whether to use a set of questions he prepared the guide or select the necessary questions in the course of the conversation.

The scope of formalized surveys is much wider and deeper than well-defined areas of treatment for an interview of the formalized type. They can be used as self-sufficient methods in research, or used in combination with other methods. The non-formalized interviews are well suitable for cultural and anthropological studies and some others, where field experience is significant (Bird, Wiles, Okalik, Kilabuk, 2009).

The semi-formalized interview represents an average quality between the already identified types. It has a few pre-canned questions on the subject, but there is no clear expectations of how they are going to be answered by the respondent.

Expert interviews are of particular interest in non-formalized or semi-formalized surveys.
Expert interview is a kind of individual interviews carried out between interviews and respondent - a specialist in the subject in question. Unlike an ordinary person this type of respondent is a carrier of deep knowledge of the research object. If the usual in-depth interviews aimed at studying the individual's personal life and his everyday opinions, the purpose of the expert interview is to obtain additional unknown or reliable information, authoritative opinions serious and professional assessments of the research topic. Therefore, the expert interview cannot be formalized. This type of research involves open nature of questions that allows the expert to tell their point of view on the issue under study, to assess or predict the possible options. Application of closed type questions in the expert interview is also possible, but with the full confidence of the researcher on the correctness of his (her) hypotheses.

Expert interviews have significant advantages over other methods of data collection. For example, due to the fact that respondents are highly qualified in the analyzed question, it eliminates the need to use additional screening and clarifying questions aimed at revealing true, but hidden from the interviewer respondent views. This type of survey is uniquely aimed at obtaining reliable data because respondents' competence is very high (Dorussen, Lenz, Blavoukos, 2005).

The procedure for expert interview retains the format of formalized or semi-formalized interviews and the survey consists of several stages. These are: choice of research topic, preparation and planning, interview, transcript of records, analysis and interpretation of data, preparation of the report.

Carrying out the expert interview implies having some skills for a researcher. In order to make the work productive the researcherinterviewer should be knowledgeable in the subject, he should understand what he (she) is 
going to study and what is the reason for the selection of an interview as a method of his (her) study. Even before the start of field work one needs to formulate the key research question - a concrete and real one. And also need to have a primary hypothesis, in order to understand what the expert needs to verify it.

In order to conduct a good research interview, it is necessary to determine the required number of experts and make the right choice of informants (Yakusheva, 2007). This is especially important when the stages of the research work are limited in time and necessary resources. Even before the direct field studies an approximate sampling model corresponding to basic research questions should be established. Then, based on the existing models thorough and reasoned selection of experts for the interview should be conducted.

Representative sampling of respondents is carried out in accordance with the criteria that are based on assessment of the competence of the expert as an expert. They are: education and skills, position, related to the research topic, work experience in the subject in question, the degree of quality of the prior expert judgments, the level of public recognition, objectivity of the submitted ratings.

The researcher I. Ya. Steinberg points out that the study sampling can be done by referring to the method of "eight-window" model developed by the author in the course of numerous qualitative research.

The main interest in the model is represented by expert window, which are are located along two axes "thinks - knows" (Steinberg, 2011). All in all it is distinguished four types of informants: the typical expert, key expert, theoretical expert and false expert (Fig. 1).

a) Typical expert is a carrier of practice experience and an explicit expert in the studied sphere. He's one of those "who knows" and says only on the basis of his knowledge.

b) In contrast, the key expert has developed analytical thinking, this is why in the interview process, he not only speaks providing factual information, but often reflects on the research topic, making independent conclusions.

c) Theoretical expert is not a direct carrier of the studied practice, but his professional activities have much in common with it. So he can express his interesting opinion on a given topic or give accompanying commentary, thus extending the idea of the object being studied.

d) False expert, unfortunately, can also be met in the research process. He does not know the practice and cannot say anything efficient for the interviewer. He can be useful only in that his ignorance and unwillingness to try to understand

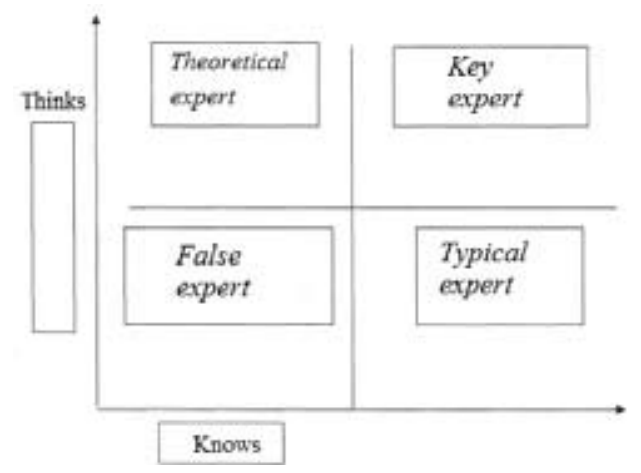

Fig.1 "Expert" windows in the "eight-window" model of sampling for the research interview" by I. Ya. Steinberg 
the issue, so that he will describe the entire institution, where he should be an expert at his post.

For the study the first three types of experts are of greatest value. Each of them can provide important information in the studied area.

In direct interview the researcher asks a series of questions to the expert on the problem in accordance with a predetermined plan of the interview, but in the course of the conversation he determines whether there is a need for additional questions or one question is enough. The interviewer must be attentive and focused on the process of conversation; he must clearly understand what the expert says, in what sense and why he says it.

The whole conversation is to be recorded on tape (Ruppert, Law, Savage, 2013), the most important information is usually written by the researcher in a paper notebook.

Data obtained from the expert interviews are processed and analyzed, than they go through systematization and interpretation.

It can be concluded that the qualitative expert interviews allows you to get valid results in cultural studies. This method is an effective tool for achieving the goals of research in the social and humanities in general, and cultural studies in particular. It is a method the results of which are presented by quality texts and not numbers of quantitative measurements.

\section{Practice of Expert Interviews in the Study of Indigenous Peoples of the North}

In November 2013 within the project "Practical models of economic and cultural development of the northern territories of Krasnoyarsk Krai, related to improving the quality of life of Indigenous Peoples of the North and Siberia and differentiated with respect to methods of management (traditional and modern) under conditions of intensive industrial development of northern and arctic regions of the Krasnoyarsk Krai", implemented with the financial support of "Krasnoyarsk Regional Fund for the Support of Scientific and Technical Activities" as well as under the state order "Developing evidencebased concept creation of mechanisms of interaction between authorities, business, ethnic and cultural groups belonging to indigenous peoples of the North, Siberia and the Far East", a group of researchers from the Department of Cultural Studies and students majoring in culture studies, master students of "History of Art" conducted a research using the method of expert interviews. In accordance with the specifics of this type of interview as experts were selected representatives of executive authorities and local self-government, whose activities are directly related to the monitoring of the quality of life, the level of culture safety of indigenous peoples, who were at the same time native representatives of a given culture.

The following respondents were selected: 1) V.H Wango - adviser to the Head of the Taimyr Dolgan-Nenets Municipal District for Indigenous Peoples; 2) S.G. Burelomova - head for the organization and ensuring the protection of native habitat and the traditional lifestyle of the indigenous peoples of the Taimyr; 3) D.B. Yaptune - leading specialist of the office of indigenous peoples of the Taimyr and issues of agriculture and fishing sector; 4) A.H. Yadne head of a reindeer breeding and agricultural cooperative "YARA-TANAMA", Dudinka; 5) A.V. Stepin - executive director of the company "YARA-TANAMA".

During the interview, the experts were asked a series of questions designed to obtain information on the topic: "The ratio of tradition and innovation in the culture of indigenous peoples". The question of the relationship between tradition and innovation in the culture of indigenous 
peoples of the North, Siberia and the the Far East is vital. The kind of answer given to this question depends on whether to keep ethnicity and its unique culture, or to disappear. On the basis of data obtained through the expert interviews we may draw the following conclusions.

In general, about the relation of tradition and innovation in the culture of indigenous people, there are two radically opposing viewpoints. The first is that the preservation of culture of Indigenous Peoples is only possible through conservation by eliminating the interaction with other cultures, to eliminate the influence of civilization, denying any innovations and traditions of absolute dominance.

Compromise is impossible because the preservation of traditional culture is only possible while preserving the traditional way of life.

The necessary conditions for preservation of indigenous cultures of the North is the preservation of the natural environment in the context of industrial development of the North and the question of securing land for grazing areas. As evidence, we consider the distant villages, access to which is complicated by the lack of transport infrastructure. Thus, in Khatanga the language, traditional methods of farming still exist.

According to the second position, the preservation of traditional culture is possible in modern conditions, but is inextricably linked to the preservation of reindeer, and even industrial development of the North cannot be an obstacle. Currently, certain steps are carried out; expertise of land areas within the area of extraction of natural resources is being done. But we should not only consider the environmental, economic aspects, but also social and cultural. As a positive factor we consider the improving quality of life of indigenous peoples through the introduction of modern technologies. Namely, this is the use of modern technology to move across the tundra, modern materials to create housing on trading stations.

If when finding an answer to the question of how to preserve the life of the ethnic group: whether to accept innovations, or to focus on the preservation of traditions, we encountered different points of view, the understanding of what "good life" is quite common.

The main indicator of a good life for indigenous peoples of the North is the number of reindeer owned by people. The more deer, the higher standard of living, wealth and power of the experience personal happiness above. Inextricably linked with this indicator is the presence of freedom: freedom of movement originally owned by indigenous lands, the use of biological resources for their needs - land for grazing deer, fish for food that is currently hampered by the active industrial development of the North. For people who do not have reindeer fishery is of paramount importance the only way for them to support themselves and their families. This raises the question about the different systems of values: villagers and nomads, residents of large cities and provinces. This difference manifests itself as a problem in the development of programs to support indigenous peoples' programs trying to implement ideas about the "good life".

The ratio of traditions and innovations in culture of indigenous peoples is also important in education. The situation here is very ambiguous. It is impossible to teach children of nomads just the way it is done with children living in towns, cities. The most comfortable form of education for indigenous peoples is a nomadic school. Nomadic school allows students to consider ethnic and cultural peculiarities, not to take them at an early age from their families that is psychologically important for a child of any ethnicity, and also allows them to maintain contact with family traditions, ethnic group. 
Nevertheless, the most widespread is such a form of training as a boarding school. But boarding schools are organized in a way that negates ethno-cultural characteristics of children and in this case classes on native speech are not a sufficient measure. Another negative feature of boarding education is that graduates who are being trained for the entire time in the "green house" conditions do not develop independence skills and graduate from boarding schools being little adapted to independent life, not able to take care of themselves, which causes considerable difficulties in their socialization. Often, young people cannot find their place in life: find a decent job, start a family. This is one of the determining factors of prevalence of alcoholism among the indigenous peoples, as well as frequent suicides.

\section{Resume}

The scope of application for the expert interview method is much broader and deeper than many other research procedures. It can be used as a self-sufficient method in cultural and anthropological issues relevant to contemporary humanities. For example, it can be applied for the study of indigenous peoples living on the territory of the North, Siberia and the Far East, culture and identity which is now endangered. This method is good because it allows you to receive unknown or more reliable information interesting for a researcher, when authoritative opinions and serious professional estimations relating to the research are taken from people whose competence is not questioned. Due to the fact that respondents in the expert interviews are highly qualified in the investigated area, it eliminates the need for additional verification procedures. Information obtained from the expert survey is valid and could cause doubts only in exceptional cases.

Application of the expert interviews gives access to the information that gives an opportunity to create a holistic view of the significance of tradition and innovation impact on the process of preservation of the traditional culture of indigenous peoples of the North and improve their quality of life. In general, the survey results indicate a need for experts to find a compromise between tradition and innovation.

To some extent, normative and legal acts need to be adopted to provide the freedom of the use of natural biological resources by indigenous peoples of the North.

- It is necessary to enhance the skills of experts in the field of culture and traditions of indigenous peoples, so that in the future we could take into account the specifics of the development of an ethno-cultural plan for the resettlement of indigenous peoples from lands that fall within the industrial development program.

- In the area of reindeer breeding it is necessary to develop a series of measures so that the reindeer breeders could sell their products. The creating of mobile stations to collect venison and fish will help to build a balance between receiving subsidies and opportunities to earn. And also it is necessary to create a system of measures to encourage people in maintaining pastures, respect for the land and biological resources.

It is necessary to provide stationary housing to indigenous peoples, engaged in traditional economic activities not only in villages but also in trading stations. New technologies in the creation of mobile housing are not as good as traditional forms (reindeer skin tents, small frame huts) in terms of providing warmth and security. For example, the traditional hut (made of wood, reindeer skins) allows $100 \%$ evacuation in case of fire, in contrast to huts made of modern plastics, iron, etc. 


\section{References}

1. S. Bird, J.L. Wiles, L. Okalik, J. Kilabuk, G.M. Egeland (2009). Methodological consideration of story telling in qualitative research involving Indigenous Peoples. Global Health Promotion, 16 (4), $16-26$.

2. D. Byrne (2005). Complexity, Configurations and Cases. Theory, Culture \& Society, 22(5), $95-111$.

3. G. E. Ciapuscio, (2003). Formulation and Reformulation Procedures in Verbal Interactions between Experts and (Semi-) laypersons. Discourse Studies, 5(2), 207-233.

4. H. Dorussen, H. Lenz, S.Blavoukos (2005). Assessing the Reliability and Validity of Expert Interviews. European Union Politics, 6(3), 315-337.

5. A. Feldman (2001). Transforming Peoples and Subverting States: Developing a pedagogical approach to the study of indigenous peoples and ethnocultural movements. Ethnicities, 1(2), 147-178.

6. J.V. Fenelon, S.J. Murguia (2008). Indigenous Peoples: Globalization, Resistance, and Revitalization. American Behavioral Scientist, 51(12), 1656-1671.

7. J. Ferguson, A. Gupta (1992). Beyond «Culture»: Space, Identity, and the Politics of Difference. Cultural Anthropolog, 1, 6-23.

8. M. Fischer (1988). Scientific Dialogue and Critical Hermeneutics. Cultural Anthropology, 3(1), 3-15.

9. K. Hayward (2006). Reiterating National Identities: The European Union Conception of Conflict Resolution in Northern Ireland. Cooperation and Conflict, 41(3), 261-284.

10. M.B. Lane, M. Hibbard (2005). Doing It for Themselves: Transformative Planning by Indigenous Peoples. Journal of Planning Education and Research, 25(2), 172-184.

11. A. Mackenzie, R. McNally (2013). Living Multiples: How Large-scale Scientific Data-mining Pursues Identity and Differences. Theory, Culture \& Society, 30(4), 72-91.

12. M. L. Martello (2008). Arctic Indigenous Peoples as Representations and Representatives of Climate Change. Social Studies of Science, 38(3), 351-376.

13. S. E. Mills (2011). Beyond the Blue and Green: The Need to Consider Aboriginal Peoples' Relationships to Resource Development in Labor-Environment Campaigns. Labor Studies Journal, 36(1), 104-121.

14. J. Robbins (2010). A nation within? Indigenous peoples, representation and sovereignty in Australia. Ethnicities, 10(2), 257-274.

15. A. Roosvall, M. Tegelberg (2013). Framing climate change and indigenous peoples: Intermediaries of urgency, spirituality and de-nationalization. International Communication Gazette, 75(4), 392-409.

16. E. Ruppert, J. Law, M. Savage (2013). Reassembling Social Science Methods: The Challenge of Digital Devices. Theory, Culture \& Society, 30(4), 22-46.

17. C. Rush, R. Roy (2001). Expert Judgment in Cost Estimating: Modelling the Reasoning Process. Concurrent Engineering, 9(4), 271-284.

18. M. Savage (2013). The «Social Life of Methods»: A Critical Introduction. Theory, Culture \& Society, 30(4), 3-21.

19. C.J. Thompson, D.M. Davis (2004). Interview with an Expert Witness of Desegregation: Reflections from Eugene E. Eubanks. Urban Education, 39 (4), 458-465. 
20. G. Whiteman (2009). All My Relations: Understanding Perceptions of Justice and Conflict between Companies and Indigenous Peoples. Organization Studies, 30(1), 101-120.

21. E.M. Andreev, (2012). Socio-cultural identity: methodological problems of research and implementation. Bulletin of the Kazan University of Technology [Sotsial'no-kul'turnaya identifikatsiya: metodologicheskiye problemy issledovaniya i realizatsii. Vestnik Kazanskogo tekhnologicheskogo universiteta], 2 (15), 94-98.

22. A. Anisimova, O. Echevskaya, (2012). "Siberian": community, nationality or "state of mind"? Laboratorium. Journal of Social Research ["Sibiryak»: obshchnost', natsional'nost' ili «sostoyaniye dushi»? Laboratorium. Zhurnal sotsial'nykh issledovaniy] (3), 11-41.

23. M.V. Belozerova (2013). On the problem of using the results of opinion polls in studying the contemporary ethnic situation. World of Eurasia [K probleme ispol'zovaniya rezul'tatov sotsiologicheskikh oprosov pri issledovanii sovremennoy etnicheskoy situatsii. Mir Yevrazii], (4/23), 2-5.

24. M. Kh. Belianskaya (2013). OLYEKMINSKY EVENKI: statistical, historical and cultural research. Bulletin of the North-Eastern Federal University named after M.K. Ammosov [Olekminskiye evenki: statisticheskoye, istoriko-kul'turnoye issledovaniye. Vestnik Severo-vostochnogo federal'nogo universiteta im. M.K. Ammosova] 2 (10), 165-170.

25. G.N. Bibikov (2011). Terminology struggle for culture: modern approaches to the study of cultural processes. Observatory of culture [Terminologicheskaya bor'ba za kul'turu: sovremennyye podkhody k izucheniyu kul'turnykh protsessov. Observatoriya kul'tury] (1), 19-25.

26. K.V. Bidnaya (2013). Traditional culture and modern social organization of Evenki. Arctic and North [Traditsionnaya kul'tura i sovremennaya sotsial'naya organizatsiya evenkov. Arktika $i$ Sever,] (12), 70-77.

27. A.O. Boronoev, (2010). Dynamic problems of Siberian identity. Society. Wednesday. Development (Terra Humana) [Problemy dinamiki Sibirskoy identichnosti. Obshchestvo. Sreda. Razvitiye ], (3), 81-85.

28. T.A. Branchun, (2010). Chukchi shamanism: religious and socio-cultural functions. Economic and humanitarian areas of research, (3), 34-44.

29. R.I. Vasilyeva, M.G. Degtyareva, N.I. Ivanova, L.N. Semenova, Contemporary ethnolinguistic situation in the Republic of Sakha (Yakutia) socio-lingual aspect, Novosibirsk, 2013, 252p.

30. N.I. Velichko (2010). Ethnicity of ethno culture as a subject of cultural studies. Society. Wednesday. development (terra humana), (3), 198-201.

31. S.N. Vinogradova (2012), Indigenous peoples in research and MTSNKO CST KSC. Bulletin of the KSC RAS, (4/11), 3-7.

32. S.N. Vinogradova (2012). Sami research and MTSNKO CST KSC: History of formation and the main results of fifteen years. Proceedings of the Kola Scientific Center (1/12), 87-101.

33. E.P. Vinokurova (2008). Ethnic cultural opportunities. Proceedings of the Russian State Pedagogical University named after A.I. Herzen (70), 122-125.

34. T.B. Vladislavlev (2011). Cultural and historical heritage as a resource for innovative development of indigenous peoples. Bulletin of the Moscow State Linguistic University, (608), 9-20.

35. E.A. Volzhanina (2009). Modern ethno-social processes of the Yamal Nenets in industrial development. Problems of history, philology, culture (25), 355-358. 
36. S.V. Guzenina (2012). Cultural identity in the focus of current research. Analysis of Cultural Studies, (24), 109-112.

37. M. Ermoshin (2008). Method latent interview as a source of expert information in the study of closed social groups. Proceedings of the Russian State Pedagogical Universityof A.I. Herzen, (55), 113-116.

38. Y.S. Zamaraeva (2010). Relevance of research on the relationship of the migrant and the host environment in the modern philosophy of culture. Science and modernity, (5-3), 96-100.

39. V.I. Ilyin, Drama qualitative field research, St. Petersburg, 2006, 256 p.

40. N.P. Karpov (2011). The study of preservation and development of cultural heritage of indigenous peoples of the Sakha Republic (Yakutia). Modern research of social problems, 1 (5), 273275 .

41. S. Kevale, Research Interview. Moscow, 2009, 301 p.

42. V.I. Kirko, S. Verkhovets, A.V. Keush (2010). The role of federal universities in shaping regional innovation structures (the example of Siberian Federal University). Innovation (10), 60-64.

43. V.I. Kirko, K.N. Zakharov (2013). Traditional economic activity - ethno-preserving lifestyle. Arctic and North (12), 24-31.

44. A.V. Kistova (2013). Methodological significance of "understanding of hermeneutics" of Wilhelm Dilthey socio-philosophical study of modern sociocultural phenomena. Modern problems of science and education, (3), 450.

45. E.A. Kozhevnikov (2013). Ethno-cultural factors of project activities in Russia: Problems and Tools (part 1). Project and program management, (2), 114-122.

46. E.A. Kozhevnikov (2013) Ethno-cultural factors of project activities in Russia: Problems and Tools (Part 2). Project and program management, (3), 218-226.

47. A.A. Kokoshin Scenarios of Eastern Siberia and the Far East in the context of the political and economic dynamics of the Asia-Pacific to 2030: Analytical Report, Moscow, Irkutsk, 2011, $120 \mathrm{p}$.

48. N.P. Koptseva, V.S. Luza State cultural policy in the Siberian Federal District: concepts, issues, research: Monograph. Krasnoyarsk, 2012.

49. N.P. Koptseva (2007). Integration of liberal education in the Siberian Federal University. Higher education today, (4), 6-8.

50. N.P. Koptseva (2007). Theory and practice of innovative educational programs for aesthetic cycle disciplines. Higher education today, (12), 9-13.

51. N.P. Koptseva (2012). The cultural base of the all-Russian national identity formation in the Siberian region of the Russian Federation. Bulletin of Volgograd State University. Series 7. Philosophy, sociology and social technologies, (3), 11-15.

52. N.P. Koptseva (2012). Methodological possibilities of social (cultural) anthropology to contemporary cultural studies. Philosophy and Culture (10), 9 -18.

53. N.P. Koptseva (2012). The problem of methodology for Contemporary Cultural Studies: Opportunities classic British social anthropology. Humanities and Social Sciences, (4), 89-104.

54. N.P. Koptseva (2013). A pilot application of cultural studies Intercultural Communication: focus groups, personal interviews, questionnaires, obtaining expert opinion (based on the study of the Krasnoyarsk Territory). Modern problems of science and education, (3), 410. 
55. N.P. Koptseva, N.M. Libakova (2013). Productivity gender approach for humanitarian studies. Modern problems of science and education (1).

56. N.P. Koptseva, N.N. Nevolko (2012). Visualization of ethnic traditions in painting and graphic works Khakassian masters. Art and Education, (1), 27.

57. N.P. Koptseva, E.A. Nozdrenko (2012). Ethnopedagogical approaches in the Siberian Federal University: the idea of a school for northern indigenous peoples of the North, Siberia and the Far East. Innovation in Continuing Education, 5 (12), 5-11.

58. Indigenous peoples of the North and Siberia under the global transformations (on the basis of the Krasnoyarsk Territory). Part 1. Conceptual and methodological bases of research. Ethnocultural dynamics of Indigenous Peoples of the Krasnoyarsk Territory [A.E. Amosov, N.P. Koptseva, N.M. Libakova, K.V. Reznikov, K.V. Sertakova, N.N. Pimenova, A.V. Kistova etc. Ans. Ed. NP Koptseva]. Krasnoyarsk: Siberian Federal University, 2012. 640 p.

59. E.A. Korczak (2013) Indigenous Peoples of the North in the state's Arctic strategy. Modern problems of science and education, (5), 390.

60. Y. Kremer (2011). Shamanic healing, psychotherapy and recognition of healing techniques, common among indigenous peoples. Ethnographic Review, (3), 40-52.

61. V.P. Krivonogov, peoples of Taimyr (contemporary ethnic processes). Krasnoyarsk: RIO KSPU 2001.

62. V.P. Krivonogov, peoples of Taimyr at the beginning of the XXI century. Krasnoyarsk: RIO KSPU, 2007.

63. O. Kuzivanova, (2012). Indigenous peoples: two approaches, the two concepts. The News of Altai State University (4-1), 249-253.

64. The culture of indigenous peoples in the context of global transformations: monograph [N.P. Koptseva, E.A. Sertakova, M.I. Ilbeykina Y.S. Zamaraeva, N.M. Libakova, V.S. Luzan et al.] St. Petersburg: Eidos, 2011. 174 p.

65. V.A. Kurennoy (2012). The research program of cultural and political studies. Philosophicalliterary journal Logos (1/85), 14-79.

66. M.S. Kuropyatnik, Indigenous peoples in the process of social change. St. Petersburg, 2005, $240 \mathrm{p}$.

67. T.I. Larin (2013). Defining quality of sociological tools based on the analysis of non-verbal reactions of respondents (experimental results). Monitoring of public opinion: the economic and social changes (5/117), 026-031.

68. Y. Latushko (2010). National and cultural revival in post-traditional societies (the problem of qualitative and quantitative assessment). Russia and the Pacific, (2), 173-180.

69. N.P. Ledovskih (2013). Methodological bases of research cultural phenomena. Russian scientific journal, (1/32), 095-100.

70. N.M. Libakova, Modifications gender images in the Russian culture of the end XIX beginning of XXI century: The dissertation ... The candidate of philosophical sciences: 24.00.01. Krasnoyarsk, 2011. 155 p.

71. V.S. Luzan (2013). Understanding of intellectual leisure contexts in modern Russian studies. Bulletin of the Krasnoyarsk State Pedagogical University named after V.P. Astafiev, 4 (26), 175-178.

$$
-125-
$$


72. V.S. Luzán, social-philosophical analysis of the dynamics of the state cultural policy of the Russian Federation: the dissertation ... The candidate of philosophical sciences: 09.00.11. Krasnoyarsk, 2011. $170 \mathrm{p}$.

73. M.M. Lukin, Technology interview. M, 2008, 188.

74. O.V. Maltsev (2013). Festive Nanai culture in modern conditions: socio-cultural aspect. Bulletin of the Tomsk State University. History (4/24), 68-71.

75. E.A. Malianov, (2010). Welfare Innovations as the direction of scientific research. World of science, culture, education, (2), 96-98.

76. V.V. Markhinin, I.V. Udalova (2012). Indigenous peoples of Ugra in the system of ethnic relations. Bulletin of the Novosibirsk State University. Series: Philosophy, (1), 56-63.

77. R. Merton, M. Fiske, P. Kendall, focused interview, Moscow, 1991, 86 p.

78. O.A. Murashko, V.K. Dallmann (2011). Transformation of the traditional lifestyle and diet of the indigenous population of the Nenets Autonomous Okrug. Bulletin of Moscow University. Series 23: Anthropology, (4), 4-24.

79. A.I. Miagkov, I.V. Zhuravlev (2005). The style of interviewing and its results. Bulletin of the University of Tambov. Series: Humanities, (2), 52-61.

80. M.S. Nafanailova (2008). Features strategies of self-concept representatives ethnic Sakha. Proceedings of the Russian State Pedagogical University. AI Herzen, (61), 436-439.

81. T.M. Nikaeva, (2013). Ethnic stereotypes in the way of the world Russian, Yakut, Evenki and Evens. Bulletin of the North-Eastern Federal University. M.K. Ammosov, 3 (10), 75-81.

82. A.A. Nikonov (2009). Cultural heritage and identity formation. Bulletin of St. Petersburg University. Episode 6: Philosophy. Jurisprudence. Politics. The right. International relations, (2), 203-209.

83. N.I. Novikov (2013). Protection of Cultural Heritage of Indigenous Peoples in the context of industrial development. Bulletin of the Novosibirsk State University. Series: History, Philology, (3), 93-101.

84. N.I. Novikov, V.V. Stepanov (2010). Indicators of quality of life of indigenous peoples of Sakhalin Oblast. Studies in applied and emergency ethnology, (217), 3 - 41.

85. Siberia's New Future: Expectations, Challenges and solutions: monograph [N.A. Bakhova, A.V. Bukharov, E.A. Viktoruk, M.I. Ilbeykina et al.] Krasnoyarsk: Sib. Fed. University, 2013.

86. D.A. Oaprina (2010). Nunavut Inuit adaptation to the new social and cultural realities. Ethnographic Review, (5), 89-106.

87. A.B. Permilovskaya (2013). The author's concept in the study of folk architecture of the Russian North. Yaroslavl Pedagogical Gazette, 2 (1), 213-217.

88. V.V. Poddubikov (2012). Indigenous peoples to sustainable development: traditional nature and the conservation of natural and cultural heritage (the experience of the Altai-Sayan Ecoregion). Modern research of social problems, (3), 55.

89. O.A. Pozdnyakova, K.V. Reznikov (2013). Features of cinema-communication of artistic subjects. Modern problems of science and education, (4), 385.

90. G.S. Popov (2013). Ethno-cultural identity in today's society. Modern research of social problems, (2/22), 40 .

91. K.V. Reznikov, Social construction of national identity in the Russian Federation: the author's dis. ... The candidate of philosophical sciences: 09.00.11. Krasnoyarsk, 2012. 20.

92. L.M. Risman (2009). On the question of qualitative methods in historical research: in-depth interview. Problems of socio-economic development of Siberia (1), 259-260. 
93. D.D. Rodionov, V.V. Poddubikov, (2012). WEB-encyclopedia "Prominent figures of science and culture, indigenous peoples of the Russian North, Siberia and Far East of Russia": the presentation of the contribution of ethnic groups in the Asian part of Russia the development of culture, arts and scientific knowledge. World of science, culture and education. (6/37), 401-403.

94. L.H. Samsitova (2012). The nature and specificity of cultural concepts in a language picture of the world. Herald Bashkir University, 3 (17), 1529-1532.

95. A.A. Semenov (2012). Visual culture modernized society. Bulletin of Volgograd State University. Series 7. Philosophy, sociology and social technologies, (3), 141-149.

96. A. A. Semenova, A.A. Gerasimov (2013). Features creative method of Sergei Anufriev. Modern problems of science and education, (2), 542.

97. A.A. Semenova, Modifications of ancient concept of "state" in Russian culture of the $21^{\text {st }}$ century: methodological aspect: the dissertation ... The candidate of philosophical sciences: 24.00.01. Krasnoyarsk, 2009. 198 p.

98. E.A. Sertakova (2013). Study of "city" in the classical concepts of foreign scientists. Modern problems of science and education. (4) 381.

99. E.A. Sertakova (2012). Cultural geography A. Lefebvre, in the light of humanitarian researches social space of the city. Theory and practice of social development, (3), 24-26.

100. E.A. Sertakova (2010). Operation works of art on the Internet. Science and modernity, (3-1), 64-68.

101. F.H. Sokolova (2013). Indigenous peoples of the Arctic: the concept, the current state of culture. Arctic and North (12), 51-69.

102. A.N. Soloviev (2009). Cultural differences as the basis of ethnic identity in the context of globalization. World of Psychology (3), 23-34.

103. A.N. Soloviev (2011). "Ethnic subculture": conceptualization of ethnicity in the context of cultural differences. International Journal of Cultural Studies (1), 6-14.

104. V.O. Tatarintzev (2010). Religious studies and cultural studies approaches to the study of traditional ecological consciousness of indigenous peoples of the North. Proceedings of the Russian State Pedagogical University. AI Herzen (137), 78-83.

105. N.M. Terebihin (2008). Religio-ethnic space of the North as the cathedral of peoples, religions and cultures. Bulletin of the Northern (Arctic) Federal University. Series: Humanities and Social Sciences, (3), 72-77.

106. T.B. Uvarov (2011). Ethnological expertise in studies of indigenous peoples, Siberia and the Far East. New Historical Journal, (29), 129-134.

107. N.T. Ulturgasheva (2010). Features of modern research traditional culture of Siberia. Bulletin of the Kemerovo State University of Culture and Arts (13), 39-48.

108. O.I. Ulyashev (2011). "Midsummer Day": a tradition in life and life in the tradition of northern Khanty. Ethnographic Review, (4), 7-14.

109. V.V. Ushnitsky (2012). Forming the backbone of the Yakut culture. Ethnographic Review, (5), 158-170.

110. O. Habek, P. Vitebsk, J. Komaroff, A. Kostopoulos, F. Navarete (2009). Ethnographic research in the North and their contribution to global anthropology: an attempt to assess the current situation. Problems of history, philology, culture (25), 371-373.

$$
-127-
$$


111. T.G. Kharamsin, V.T. Kharamsin (2011). Sociology of culture of indigenous peoples: the theory of matter. Ugric Herald, (1), 174-178.

112. N.A. Conjugate (2005). Traditional culture in the era of globalization. Traditional culture, (2), 52-59.

113. I.V. Chekhov (2009). Interviews as a way to obtain information in a qualitative research strategy search. Bulletin of the Russian Peoples' Friendship University. Series: Sociology, (4), 20-25.

114. I.V. Chekhov (2013). Focus groups: stages of the study. Bulletin of the Russian Peoples' Friendship University. Series: Sociology (4), 145-155.

115. I.V. Chekhov, The Method of Focus Groups. Ph.D. dissertation, Moscow, 2011, 155 p.

116. O.V. Churakova (2010). Symbolic representation of the female in the traditional cultures of the European North. The problem of preserving ethno-gender identity of northern women. International Journal of Cultural Studies (1), 106-111.

117. I. Ya. Steinberg (2011). Eight-window sampling model for the research interview. Available at: http://fieldsociology.blogspot.ru/2011/12/blog-post.html.

118. V.I. Yudin (2013). The language and culture of the Sami people in the public policy of the Nordic countries. Bulletin of the Moscow State University of Culture and Arts (4/54), 50-55.

119. A.A. Yausheva, (2007). Sampling: the search for new opportunities. SOCIS. Sociological studies, (8), 90-96.

120. J.W. Berry, P.R. Dasen, A.K. Purtinga, M.H. Sigal, Cross-cultural psychology. Research and application, Kharkov, 2007, 560 p.

121. E. Bell, A. Braymen, Methods of Social Research. Groups, organizations and business, Kharkov, 2012, 776 p.

122. H.R. Markus, S. Kitayama (1998). The cultural psychology of personality. Journal of CrossCultural Psychology, (29), 63-87.

123. H.C. Triandis, M. Gerardo (1983). Etic Plus Emic Versus Pseudoetic: A Test of a Basic Assumption of Contemporary Cross-Cultural Psychology. Journal of Cross-Cultural Psychology, (14), 489.

124. L.D. Surmanidze (2004). Culture: Contemporary empirical research trends. Man: the ratio of national and universal. Sat Proceedings of International Symposium (Zugdidi, Georgia, 19-20 May 2004), (2), $225-238$.

125. W. Dallmann, H. Goldman (2003). Indigenous - native - aboriginal: Confusion and translation problems. available at: http://www.npolar.no/ansipra/russian/Items/ConfusionR.html.

126. M.S. Kuropyatnik (2002). From stigma to self-assertion: the concept of "indigenous people" in contemporary discourse. Journal of Sociology and Social Anthropology, (5/1), 161-173. 


\title{
Метод экспертного интервью \\ как эффективная исследовательская процедура \\ изучения индигенных народов Севера
}

\author{
Н.М. Либакова, Е.А. Сертакова \\ Сибирский федеральный университет \\ Россия, 660041, Красноярск, пр. Свободный, 79
}

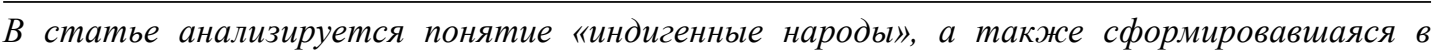
культурных исследованиях индигенная концепция, подразумевающсая особый подход к изучению этнических культур в их самодостаточности. Одним из эффективных методов, отвечающим требованиям данного подхода, является экспертное интервью. В статье рассматриваются возможности применения данного метода в исследованиях индигенных народов Севера на материале, полученном учеными, магистрами и студентами Сибирского федерального университета в ходе экспедиции на Север Красноярского края.

Ключевые слова: индигенные народы, коренные малочисленные народы Севера, этническая идентичность, культурные исследования, исследовательские прочедуры, метод экспертного интервью.

Научное направление: 24.00.00 - культурология. 